\title{
Erosional history of the Karkonosze Granite Massif - constraints from adjacent sedimentary basins and thermochronology
}

\author{
Piotr MIGOŃ and Martin DANIŠÍK
}

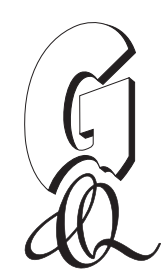

\begin{abstract}
Migoń P. and Danišík M. (2012) - Erosional history of the Karkonosze Granite Massif - constraints from adjacent sedimentary basins and thermochronology. Geol. Quart., 56 (3): 441-456, doi: 10.7306/gq.1032

The long-term erosional history of the Karkonosze Granite Massif is revised and reconstructed using different sources of information, including the sedimentary record of adjacent basins, previously published low-temperature thermochronological data and geomorphic features. Although the evidence is still incomplete, this work has identified a number of intervals, of unequal duration, characterized by different denudation regimes and rates. Several major phases of rapid exhumation are inferred - in the Permian and the Early Triassic as seen in the sedimentary record, and in the Late Cretaceous as shown by both the thermochronological and sedimentary records. Neotectonic uplift of the Karkonosze Mts. in the late Cenozoic is not recorded in the thermochronological record and there is no evidence of any accelerated denudation close to the massif. Apatite fission track data show that $>\sim 3.6 \mathrm{~km}$ of rock must have been eroded since the Turonian, while the results of zircon (U-Th)/He analysis suggest that in places erosion of $>\sim 6 \mathrm{~km}$ of rock must have taken place. This picture differs from previous estimates of denudation which suggested that only $2-2.5 \mathrm{~km}$ has been eroded from the axial part of the Karkonosze dome since the exposure of granite batholith in the Permian.
\end{abstract}

Piotr Migoń, Department of Geography and Regional Development, University of Wrockaw, Uniwersytecki 1, 50-137 Wroctaw, Poland, e-mail: piotr.migon@uni.wroc.pl; Martin Danišik, John de Laeter Centre of Mass Spectrometry, Applied Geology, Curtin University of Technology, GPO Box U1987, Perth WA 6845, Australia; now at Department of Earth and Ocean Sciences, The University of Waikato, Private Bag 3105, Hamilton 3240, New Zealand, e-mail: m.danisik@waikato.ac.nz (received: November 25, 2010; accepted: April 20, 2012; first published online: August 1, 2012).

Key words: Karkonosze, Sudetes, erosional history, thermochronology, sedimentary basins.

\section{INTRODUCTION}

The Karkonosze Mountains (German: Riesengebirge) have long been the subject of research on landform evolution both on short and long timescales. As they constitute the highest massif within the extensive belt of Central European mountains and uplands (German: Mittelgebirge), they may serve as a reference point for a much larger area.

The granite of the Karkonosze (mid/late Carboniferous in age; Duthou et al., 1991; Machowiak and Armstrong, 2007) was exposed as early as in the early Permian (Berg, 1938). Since no deposits from later geological periods occur in the Karkonosze, except for late Quaternary glacial and hillslope deposits, classic geological evidence alone fails to reconstruct the long-term topographic, erosional and thermal evolution of the massif after exposure of the granite (e.g., Mierzejewski, 1985). In addition, denudation chronology approaches based on identification of remnants of planation surfaces (e.g.,
Ouvrier, 1933; Sekyra, 1964), have been dismissed as highly speculative and unconstrained (Jahn, 1954; Danišík et al., 2010).

In this review, published thermochronological data from Danišík et al. (2010) and other sources is combined with the sedimentary record from adjacent basins and relevant geomorphic and weathering features in order to constrain the long-term erosional history of the Karkonosze granite. In postVariscan times Central Europe was subject to a series of major tectonic events (see Reicherter et al., 2008; Scheck-Wenderoth et al., 2008, for reviews) and we investigate how the denudation of the Karkonosze granite area may have responded to them. We focus on the post-exposure period because of two reasons. First, this period is now relatively well-covered by low-temperature thermochronological data, whereas all existing high-temperature geochronological data from $\mathrm{U}-\mathrm{Pb}$ to ${ }^{40} \mathrm{Ar}-{ }^{39} \mathrm{Ar}$ systems, covering the temperature range from 350 to $\sim 1000^{\circ} \mathrm{C}$ give Variscan ages ( $\left.\sim 350-300 \mathrm{Ma}\right)$. Thus, essentially our story starts where the majority of the others end (e.g., 
Mazur et al., 2006). Second, we are interested in the geomorphic history of granite massifs, which may contribute to the general understanding of long-term erosion of such massifs (see Migoń, 2006a).

There are several studies of long-term erosion of Paleozoic basement massifs in Europe based on thermochronology, but these are not always integrated with other possible sources of relevant information (e.g., our previous study from the Karkonosze area - Danišík et al., 2010). In the regional context, this study is an attempt to explicitly link thermal history with the tangible record of erosion in adjacent sedimentary basins and as such, follows and builds upon the previous thermochronological studies of Danišík et al. (2010, 2012) from the Karkonosze granite and the eastern part of the Sudetes.

\section{STUDY AREA}

\section{GEOGRAPHICAL AND GEOLOGICAL SETTING}

The Karkonosze Mountains are a part of the Sudetes, a mountain range in the north-east corner of the Bohemian Massif (Fig. 1A). The Sudetes are about $300 \mathrm{~km}$ long and 80-100 km wide, elongated from NW to SE. Mountain fronts separate the Sudetes from the surrounding lowlands and the
Sudetes, as a whole, are considered a large horst subjected to neotectonic uplift (Reicherter et al., 2008). They are divided into a mosaic of crustal blocks which have undergone differential uplift or subsidence in the late Cenozoic, as inferred from the apparent youth of tectonic landforms and the nature of correlative deposits around the range (Dyjor, 1975; Zuchiewicz et al., 2007). The spatial pattern of these movements is not entirely clear, but different methods, mainly geomorphological and morphometric, have been used to study activity of individual faults and structures (Krzyszkowski et al., 1995; Badura et al., 2007; Štěpančíková et al., 2010).

The Karkonosze Mts. are considered as one of such fault-bounded blocks in the West Sudetes, uplifted by $600-1100 \mathrm{~m}$ with respect to the adjacent basins and uplands. In map view, they form a roughly rectangular block of WNW-ESE extension, with generally clearly defined northern, eastern and southern topographical boundaries (Fig. 1B). By contrast, the western boundary with the Izerskie Mts. is indistinct with only a small drop in elevation. A notable feature of the Karkonosze Mts. is their discordant relation to major regional geological boundaries (Fig. 2). The southern and eastern boundaries roughly follow the contact of early Paleozoic metamorphic rocks with Carboniferous/Permian strata, whereas the northern boundary - the most distinct of all - cuts across the granite batholith. The somewhat arbitrarily drawn western boundary is perpendicular to the extension of both the granite and its metamorphic cover. The main water divide between the

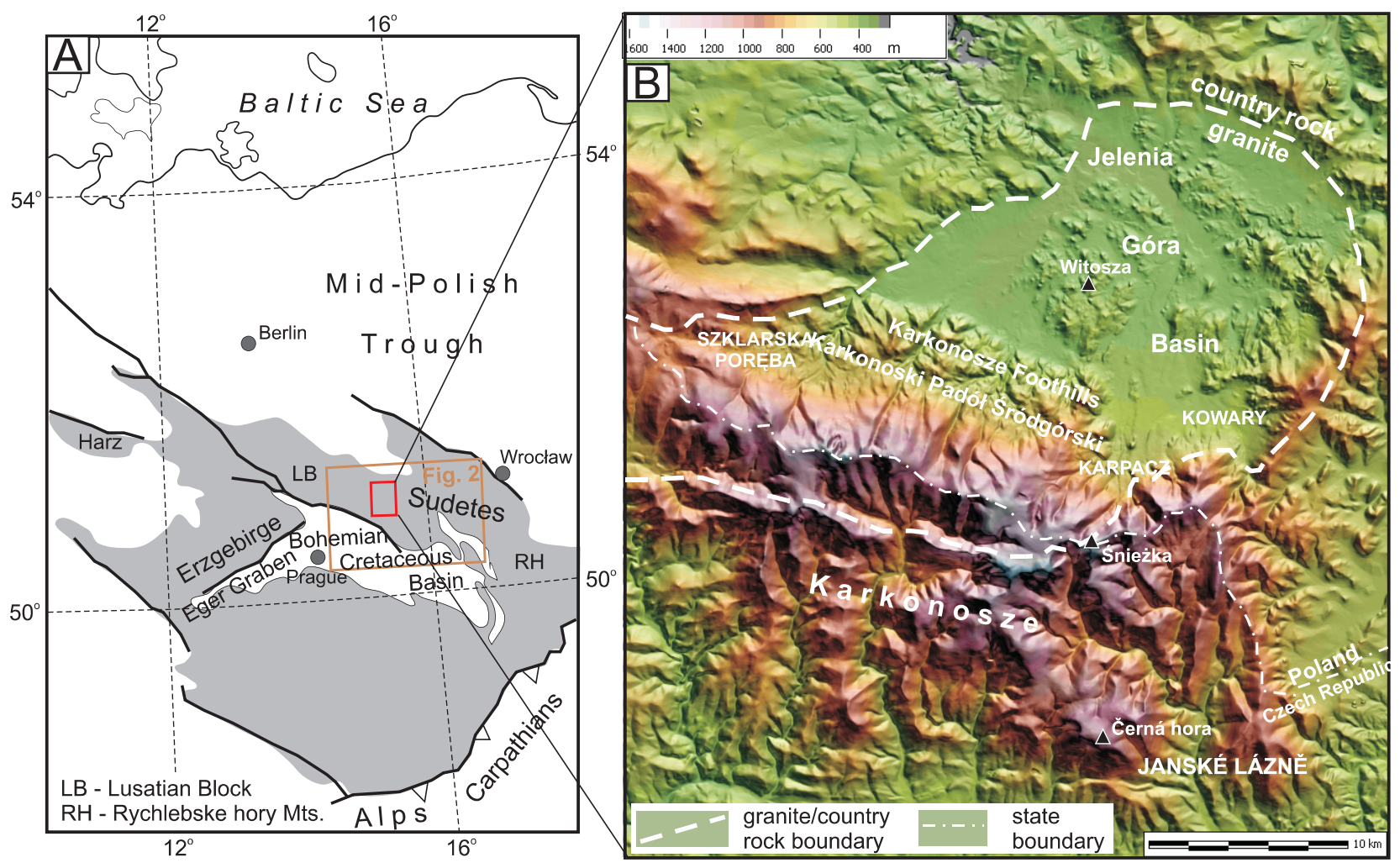

Fig. 1A - study area within Central Europe (shaded area indicates outcrops of the basement rocks of the Bohemian Massif); B - major topographic features of the Karkonosze Mountains and their surroundings shown on a digital elevation model generated with the aid of Microdem 12.0 software, from DTED2 data (resolution $50 \times 50 \mathrm{~m}$ ) 
Labe (south) and Odra basins (north) runs along the main ridge of the Karkonosze Mts.

Geologically, the Karkonosze Mts. are composed of two main units. The northern part, which is of principal interest in this paper, is composed of Variscan granite. By contrast, Variscan low- and medium-grade metamorphic rocks, represented by gneisses, mica schists, phyllites and amphibolites formed from Neoproterozoic and Cambrian intrusive, volcanic and sedimentary rocks, occur in the southern and eastern part (Fig. 2; e.g., Mazur et al., 2006). Together, they form the geological unit of the Karkonosze-Izera Massif, whose internal structure, pre-Variscan and Variscan history have been reviewed in Mazur et al. (2006).

The Karkonosze Granite Massif is a composite body, formed of two main variants. The northern part is dominated by coarse-grained granite, often of porphyritic texture with large $\mathrm{K}$-feldspars. The coarse-grained granite is locally intruded by a medium- to fine-grained granite, which forms stocks varying from a few tens of metres to nearly $2 \mathrm{~km}$ in diameter, and by numerous late-magmatic veins of aplite, lamprophyre and microgranite. The coarse-grained granite extends from the Karkonosze to the adjacent Jelenia Góra Basin. In the south the granite is generally finer and large K-feldspars are rare. The porphyritic granite and the fine-grained granite have yielded $\mathrm{Rb}$-Sr whole rock isochron ages of $329 \pm 17 \mathrm{Ma}$ and $310 \pm$ $14 \mathrm{Ma}$, respectively (Pin et al., 1987; Duthou et al., 1991), which are consistent with age determinations by other methods such as ${ }^{40} \mathrm{Ar}-{ }^{39} \mathrm{Ar}$ (Marheine et al., 2002) and SHRIMP U-Pb zircon (Machowiak and Armstrong, 2007).

The Karkonosze-Izera Granite Massif and other parts of the Variscan basement are surrounded by sedimentary basins, which preserve an erosional record of the basement since the Variscan orogeny (Fig. 2). These are the Intra-Sudetic Trough (IST) in the east, the North-Sudetic Trough (NST) in the north, the Karkonosze Piedmont Basin (KPB) in the south, and the Bohemian Cretaceous Basin (BCB) in the south-west. The sedimentary infill of the IST and NST temporarily spans the interval from the Carboniferous to the Cretaceous; the KPB records depositional history in the Permian, whereas the $\mathrm{BCB}$ gives insights into sedimentation patterns in the Late Cretaceous. A dense network of faults crosses the West Sudetes, including the Lusatian Fault, itself an eastern extension of the European-wide Elbe Zone (Scheck et al., 2002).

\section{GENERAL RELIEF}

The Karkonosze Mts. can be divided into three main terrain units (Fig. 1B). The axial part is occupied by an elevated, undulating plateau at $c a$. 1300-1500 m a.s.l., undercut by glacial cirques and dissected by the headwater reaches of the Labe River. To the south, the plateau terminates against a distinct ridge built of metamorphic rocks adjacent to the granite pluton, which includes Śnieżka (1603 m a.s.l.) - the highest peak in the

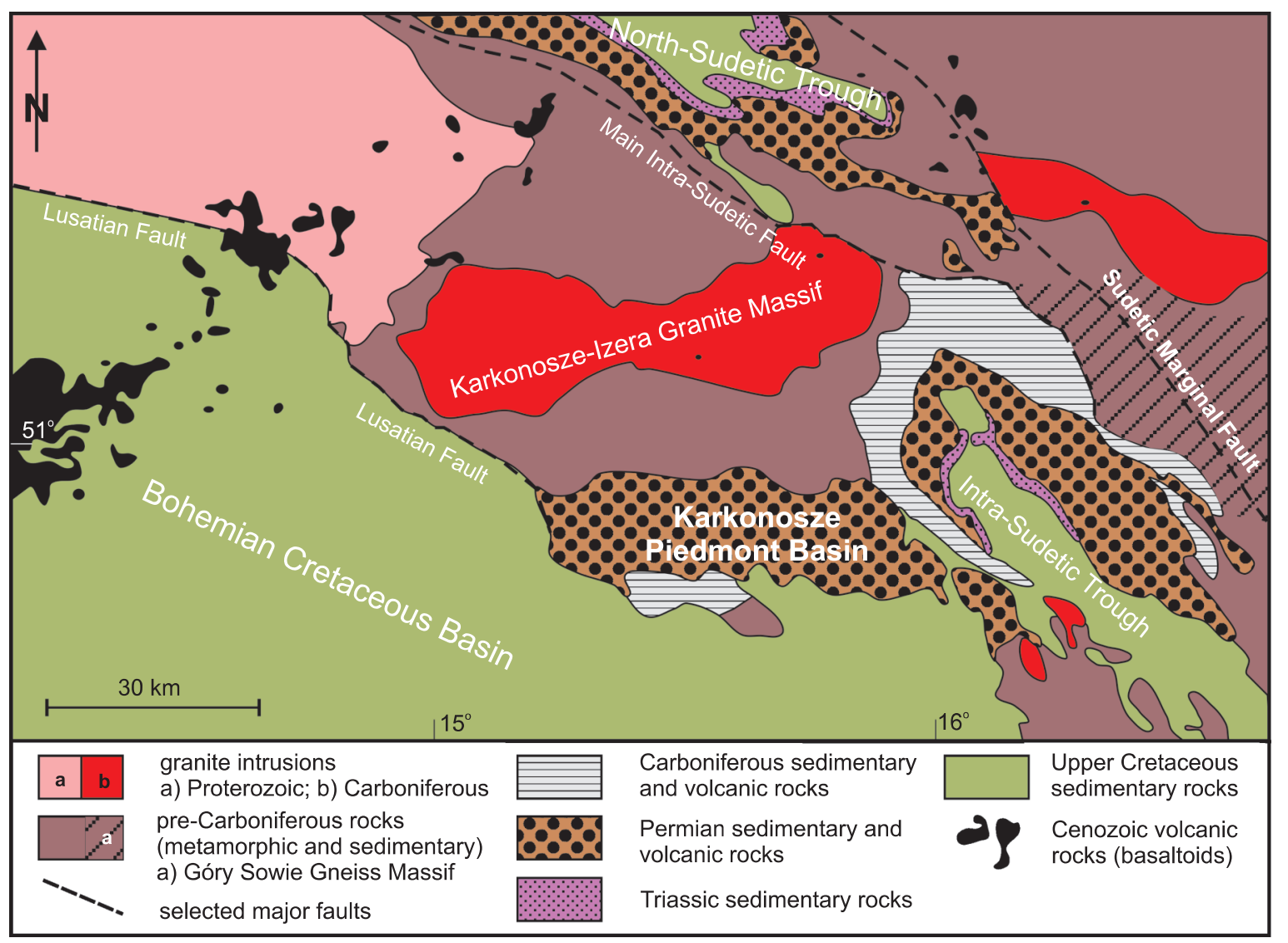

Fig. 2. Geology of the West Sudetes (after Kozdrój et al., 2001, modified) 
area. The watershed plateau is restricted to the granite area. In the metamorphic rock area east of Śnieżka it is replaced by a narrow dividing ridge.

The northern part of the Karkonosze Mts., dominated by granite, but including also its metamorphic envelope in the east, shows stepped topography (Berg, 1927; Jahn, 1954). The watershed plateau grades into a long and poorly dissected N-facing slope which descends to the intramontane trough at 600-700 m a.s.l. (Fig. 1B). Further to the north, a belt of dissected hilly terrain at 500-869 m a.s.l., known as the Karkonosze Foothills, occurs. This area terminates in a distinct mountain front overlooking the Jelenia Góra Basin.

The part of the Karkonosze Mts. south of the watershed surface, no longer within granite, is characterized by a very different morphology. It is considerably dissected by a series of broadly parallel, $\mathrm{N}-\mathrm{S}$ trending valleys, between which sinuous and narrow dividing ridges are located. Bedrock channel reaches are common. There is a general slope to the south, although differences between the western and eastern part occur. In the west, the decline in altitude is gradual and the boundary of the Karkonosze Mts. is marked by a series of E-W trending valleys, whereas in the east, near Janské Lázně, an imposing topographic step 500-600 $\mathrm{m}$ high delimits the range (Fig. 1B).

\section{POST-VARISCAN HISTORY OF THE KARKONOSZE GRANITE ACCORDING TO PREVIOUS RESEARCH}

Very few attempts have been made to reconstruct the long-term erosional history of the Karkonosze granite. Three lines of inquiry may be identified, namely geomorphological, geological and thermochronological.

Geomorphologists have long noted the unusual watershed topography of the Karkonosze Mts. and interpreted the widespread summit flats as remnants of a planation surface, uplifted to the present-day elevation (e.g., Berg, 1927; Ouvrier, 1933; Jahn, 1954; Sekyra, 1964). Hence, they divided the geomorphic history of the Karkonosze area into essentially two major stages. An older phase of regional planation was followed by a phase of tectonic differentiation of topography. Several authors argued for intermittent uplift and incision throughout the Neogene and Quaternary, using elements of planar relief at different elevations as corroborating evidence (e.g., Ouvrier, 1933; Sekyra, 1964). Others invoked differential uplift in the latest Neogene as a mechanism to explain the presence of flat relief at different altitudes (e.g., Migoń, 1991). The main weakness of geomorphic inquiries was the inability to constrain the timing of morphogenesis and therefore any "ages" given in the above-mentioned publications cannot be regarded with confidence. Pre-Cenozoic evolution was not considered in geomorphological studies.

Two geological approaches merit special attention, both including quantitative estimates of long-term denudation. Skoček and Valečka (1983) calculated the sediment volume of Upper Cretaceous sandstones deposited in the northern part of the Bohemian Cretaceous Basin (Fig. 2) and concluded that $\sim 2000 \mathrm{~km}^{3}$ of sediment is preserved. They argued that $700 \mathrm{~m}$ of denudation of the source area - the "West Sudetic Island" (which includes the area of Karkonosze; see below), was required to account for this volume. This value, however, should be considered as a minimum estimate for at least two reasons. First, an unknown proportion of sediment must have been exported to distal sinks, including a large part of the silt fraction, most of the clay and virtually all the dissolved load. If the Alps are used as an analogue, this portion would make up at least half of the total budget (Kuhlemann, 2000). Second, an unknown thickness of the Cretaceous succession was lost during post-depositional erosion.

Another attempt to reconstruct the exhumation and erosion history of the Karkonosze granite and to derive long-term denudation rates was presented by Mierzejewski (1985). This model was based on the assumption that $\sim 3.5 \mathrm{~km}$ of granite has been removed since unroofing and $\sim 2.2 \mathrm{~km}$ since the Turonian. The former figure arises from a tentative reconstruction of the original shape of the pluton based on magmatic foliation and geological cross-sections provided by Cloos (1925), whereas the latter is based on the apatite fission track age of 94 Ma reported by Jarmołowicz-Szulc (1984). Although JarmołowiczSzulc (1984) reasonably estimated the amount of post-midCretaceous erosion, Mierzejewski (1985) did not consider the majority of her data and conclusions and came up with the different estimate by assuming a mean geothermal gradient of $40^{\circ} \mathrm{C} / \mathrm{km}$ in the last $100 \mathrm{Ma}$. Mierzejewski (1985) suggested a possible increase in denudation rates towards the later Cenozoic as a side-effect of faulting and uplift in the Neogene, but did not consider any phases of accelerated denudation earlier in the Cenozoic or in the Mesozoic (Fig. 3).

\section{PRE-QUATERNARY SEDIMENTARY RECORD IN THE ADJACENT BASINS}

Denudation of the Karkonosze granite since its exposure provided clastic material to adjacent sedimentary basins, which were located east, south and north of the source area (Fig. 2). Although these proximal basins likely contain only a fraction of the sediment that was eroded away, they are considered the key source of evidence since it is here where coarse facies, indicative of vigorous erosion and high transport capacity from the source area, will be deposited. In terms of source-to-sink models, they include alluvial fans, gravel-bed braided rivers next to mountain fronts, and near-shore facies for land/sea borders. Consequently, the sedimentary records of these basins will be mainly used to constrain both the timing of erosion and its varying magnitude through time and to identify periods of increased sediment supply. However, more distant ( $>150 \mathrm{~km})$ depositional areas such as the Mid-Polish Trough will also be considered although scale considerations dictate that these faraway areas are unlikely to give precise information about the erosion of the relatively small Karkonosze granite area. Rather, they can be tied to the denudation of the Sudetes as a whole, which is not the principal subject of this paper. It is obvious that coarse proximal deposits may be lost due to subsequent ero- 


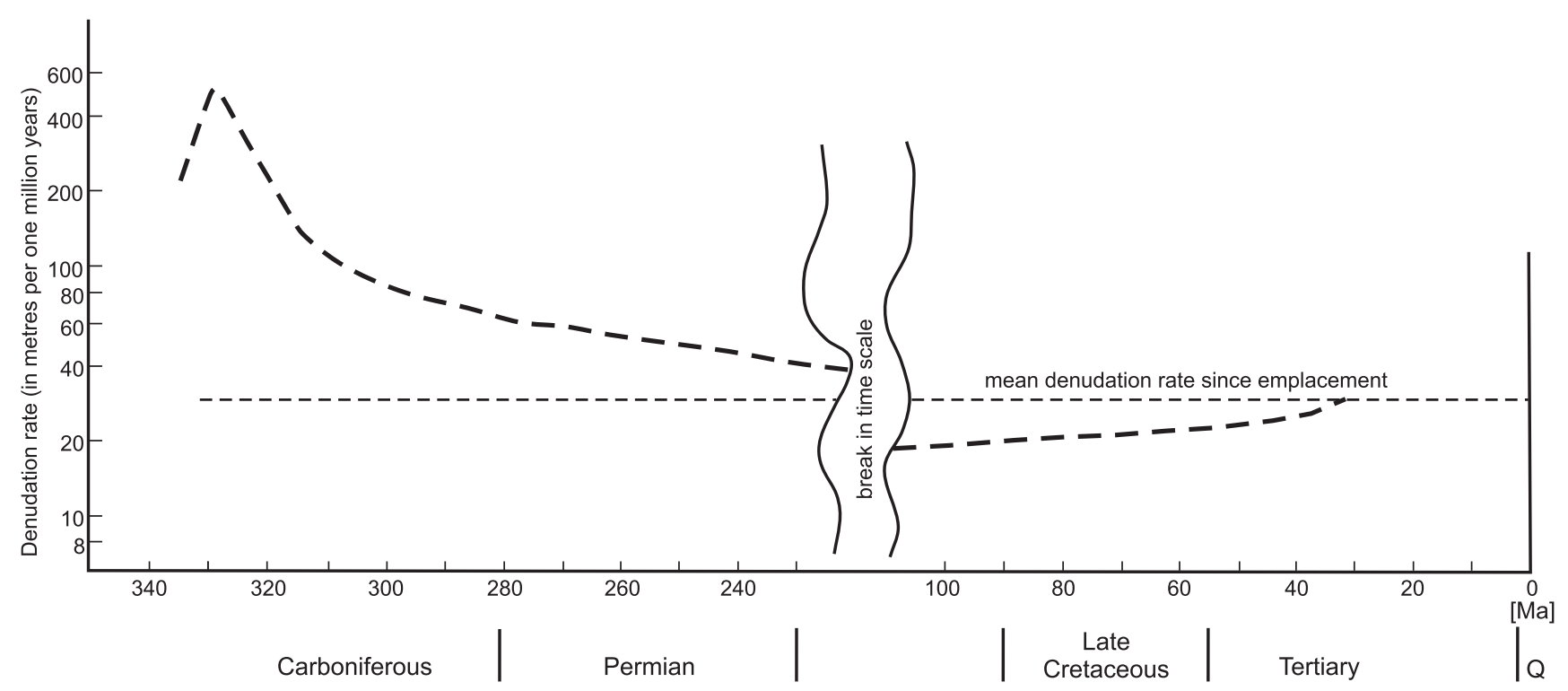

Fig. 3. Long-term erosion of the Karkonosze after Mierzejewski (1985)

Geological timescale as in the original figure

sion, but then thermochronological data should help to recognize significant erosional events whose sedimentary record was otherwise lost.

\section{PERMIAN AND TRIASSIC}

Exposure of the Karkonosze granite likely occurred in the late early Permian (Saxonian) as indicated by the presence of granitic pebbles in deposits of the adjacent Intra-Sudetic Basin (Berg, 1938). However, it needs to be seen in the wider context of long-term degradation of Variscan mountain terrains, continuous throughout the Carboniferous and early Permian with varying intensity (e.g., Turnau et al., 2002). Wojewoda and Mastalerz (1989) identified at least three mega-cyclothems for the Stephanian-Autunian interval, each commencing with alluvial fan deposits, followed by fluvial sedimentation and terminating with lacustrine (or aeolian) sediments. Erosional truncation of the upper part of the cycles indicates episodic relief rejuvenation. A new depositional cycle began in the late Saxonian and is indicated by sudden replacement of previously dominating lacustrine facies by fluvial and alluvial fan deposits, recorded both east and south of the Karkonosze granite outcrop area, in the IST and in the KPB, respectively (Blecha et al., 2008; Burliga et al., 2008). These coarse-grained deposits of braided rivers and debris flows are now exposed in numerous sections along the southern margin of the Karkonosze Mts. and in the western part of the IST. Such high energy transport is thought to be facilitated by both increasing relief and a shift to aridity, with occasional downpours and flash floods over poorly vegetated terrain. Climate aridification is inferred from widespread calcrete deposits and other pedogenic features, as well as from facies change in lacustrine deposits (Śliwiński, 1980). Don et al. (1981) noted that the presence of granite clasts in the Saxonian deposits in the northwestern part of the IST is subordinate in the lower part of the sequence, but becomes dominant in the middle part. The upper part of the Saxonian sequence is represented by much finer deposition, locally aeolian, and signals a state of advanced degradation of the source area. Similar to the KPB and IST, the lower Permian lithostratigraphy of the NST indicates coarsening of deposits in the Saxonian and hence suggests an increase of relief (Mroczkowski and Skowronek, 1980; Mastalerz, 1990). Likewise, the sudden appearance of abundant granite clasts in the Permian deposits of the NST of roughly the same age (Upper Rotliegend) shows that the source area became dominated by granite (Milewicz, 1965).

In the late Permian the area of the West Sudetes was largely planed off, as inferred from the nature of contemporaneous deposits preserved in the above-mentioned areas of deposition. These are siltstones, fine-grained sandstones, calcrete and gypsum horizons (Lorenc and Mroczkowski, 1978; Śliwiński, 1980), as well as shales, limestones, dolomites and marls of marine origin (Raczyński, 1997). Terrestrial sandy sedimentation in braided river systems resumed in the Early Triassic (Buntsandstein), indicating renewed relief, but the bulk of these Lower Triassic sandstones is a product of reworking of older Permian deposits (Mroczkowski, 1972, 1977). Clastic sedimentation in the Early Triassic was followed by carbonate sedimentation in the Mid-Triassic. Today, limestones of this age are only preserved along the northern fringe of the Sudetes, $c a$. $40 \mathrm{~km}$ north of the Karkonosze Mts., but how extensive the primary carbonate platform may have been remains unknown. No sedimentary rocks from the remaining part of the Mesozoic until the Late Cretaceous exist either inside or around the Sudetes, except for a series of very small outcrops of Jurassic limestone at the Lusatian Fault, ca. $40 \mathrm{~km}$ and more westwards from the westernmost tip of the Karkonosze Granite Massif (Voigt, 
2009), and their nearest widespread occurrence is in the Mid-Polish Trough, more than $150 \mathrm{~km}$ away from the Karkonosze Mts. Again, it is uncertain whether they never existed in the Sudetes or were stripped away before the onset of the Late Cretaceous transgression. No weathered residua from this period can be identified in the Karkonosze area, although they are widely present elsewhere in the Bohemian Massif being broadly referred to as pre-Cenomanian (Migoń and Lidmar-Bergström, 2001), and the geological history between ca. 230 and 90 Ma remains unknown.

\section{CRETACEOUS}

Sedimentation within the northern part of the Bohemian Massif resumed at the beginning of the Late Cretaceous and shortly became widespread in the area occupied by the present-day Sudetes. Except at the base of the Cenomanian, Cretaceous sediments are entirely marine, ranging from near-shore gravel through thick massive cross-bedded sandstones to mudstones and marls (Milewicz, 1997; Wojewoda, 1997; Uličný et al., 2003). Turonian sandstones account for most of the sediment volume preserved east of the Karkonosze area, in the IST, while in the BCB also Coniacian and, in the western part, Santonian deposits occur (Skoček and Valečka, 1983; Wojewoda, 1997; Uličný, 2001). However, Turonian deposits in the NST are mainly marls and marly claystones, suggesting different patterns of sediment delivery to the north (Milewicz, 1997), unless coarse facies have been eroded. Interestingly, proximal Cretaceous sedimentary basins occupied similar localities as did the Permian basins, indicating repetitive patterns of topographic highs and lows in the West Sudetes, although the extent of these basins within the present-day Sudetes may have been larger, especially in the latest Cretaceous. The youngest Cretaceous rocks in the IST are of late Turonian age (90-89 Ma), in the northern part of the BCB of Coniacian age (89-86 Ma), and those in the NST are of Santonian age ( $\sim 86-83 \mathrm{Ma})$. However, it is not exactly known how much of the Cretaceous column was lost due to later erosion. Wojewoda (1997) stated that as much as $1 \mathrm{~km}$ may be missing given the level of compaction, but did not provide primary data. In contrast, the reset fission track system in apatites in a Turonian sandstone from the IST implies that $>4 \mathrm{~km}$ of Cretaceous strata is missing in the eastern Sudetes (Danišík et al., 2012). Likewise, it is uncertain, whether the Cretaceous cover ever extended over the entire West Sudetes, including the Karkonosze area, which would be consistent with their complete submergence in the Late Cretaceous.

Leaving early Permian deposition in intramontane basins aside and allowing for the missing parts of the sedimentary record, it is obvious that the Late Cretaceous must have been quite exceptional in the long-term denudation history of the Karkonosze area in terms of rates of erosion. Possibly, the Turonian represented the peak of post-Paleozoic sediment delivery from the Karkonosze area to the surrounding basins. In this context, Uličný et al. (2003) remarked that "Significant sediment yield from the relatively small area of the Western Sudetic Island (generally, the Lusatian Block) suggests a relatively rapid mid-Cretaceous uplift, but no quantitative data on possible uplift rates and total magnitude are available". We will turn back to this point in the concluding section.

In the Late Cretaceous, widespread basin inversion in central Europe took place and basement blocks of the Bohemian Massif were up-thrusted, as an effect of either the collision of the Austro-Alpine orogenic wedge with the European passive margin (Ziegler and Dèzes, 2007) or Africa-Iberia-Europe convergence (Kley and Voigt, 2008). Whichever the exact cause, this tectonic event resulted in the formation of a series of NW-SE trending swells and troughs in Central Poland and $\mathrm{E}-\mathrm{W}$ trending comparable structures in Germany, including the Mid-Polish Swell (e.g., Krzywiec, 2006). How the Karkonosze Granite Massif may have been affected remains unknown, although the long-lived Lusatian Fault, which separates the basement block of the West Sudetes from the BCB, was clearly active during this period, accounting for brittle deformation of Cretaceous (Cenomanian) rocks (Coubal, 1990; Uličný et al., 2003; Voigt, 2009). Exposures at Mála Skála, where the Lužice Fault Zone makes the northern boundary of the $\mathrm{BCB}$, show the effects of this major deformation event. However, no sediments of latest Cretaceous/Paleocene age exist anywhere near the Karkonosze Mts. to provide an independent time-constraint. Yet, deformation must have been terminated before the Eocene as the deposits of this age overlie Cretaceous sedimentary rocks in the Ohře/Eger Graben (Malkovský, 1979).

\section{PALEOGENE AND NEOGENE}

Wider palaeogeographic reconstructions of Central Europe (e.g., Ziegler and Dèzes, 2007; Jarosiński et al., 2009) suggest that in the Paleogene the Sudetes, including the Karkonosze area, formed a part of the so called Meta-Carpathian Swell, a modestly elevated topographic high of E-W extension. Widespread weathered residuals of Paleogene/early Miocene age along the Swell (Migon and Lidmar-Bergström, 2001), but not in the Karkonosze area itself, indicate both rather subdued topography at that time and good preservation potential afterwards. No Paleogene deposits are known from anywhere around the Karkonosze Mts. in a radius of $\sim 50 \mathrm{~km}$; the nearest extensive sedimentary basin was that along the Mid-Polish Trough, where marine and terrestrial environments alternated (Piwocki, 2004). Upper Eocene ( 37 Ma) deposits found near Głogów, $\sim 90 \mathrm{~km}$ from the Karkonosze Granite Massif, are the nearest locality but these deposits do not yield any conclusive information about the denudation of the Karkonosze granite or, of the Sudetes as a whole, although their predominantly fine-grained composition along the southern boundary of the basin (Dyjor, 1974) suggests little relief in the source area and rather slow rates of erosion of the source area. To the west of the Karkonosze area, intermittent sedimentation occurred since the Eocene in local fault-controlled grabens along the Ohře (Eger) Rift more than $150 \mathrm{~km}$ to the west (Malkovský, 1979, 1987), but source areas were predominantly those adjacent to the grabens (the present-day Erzgebirge and the inner Bohemian Massif) and no link with the denudation of the West Sudetes can be established with confidence. 
Sedimentation in tectonic grabens immediately north of the Sudetes commenced in the Early Miocene (Dyjor, 1975), as it did in the intramontane Żytawa Trough at the easternmost end of the Ohře Rift (Kasiński and Panasiuk, 1987). There are patches of Miocene fluvial deposits south of the Sudetes (Prosová, 1974) but no comparable deposits have been found inside the Sudetes. Except for the immediate proximity of fault scarps, Lower and Middle Miocene deposits are generally fine-grained, indicative of low-energy fluvial systems, lakes and wetlands (Dyjor, 1986; Badura and Przybylski, 2004). Fluvial and swampy deposits of Middle Miocene age are known from the Izerskie Foothills near Leśna, $\sim 30 \mathrm{~km}$ north-west from the Karkonosze, where they survived until covered by a protective cover of Miocene basalt (Oberc and Dyjor, 1973). Coarse gravel deposition is of a later date, starting in the latest Miocene ( 7-5 Ma), and was preceded by the widespread deposition of clay and silt around the Sudetes (the "Poznan Series"; Dyjor, 1970). However, relating this major sedimentary change to the denudation history of the Karkonosze granite area requires caution, as there is uncertainty concerning the environmental interpretation of the Upper Miocene deposits. The long held view that the Poznan Series consists of predominantly lacustrine deposits (Dyjor, 1992) has recently been challenged with a fluvial environment proposed instead (Badura and Przybylski, 2004; Piwocki et al., 2004).
The nearest location of correlative deposits of pre-Quaternary age is north of Jelenia Góra, in the northernmost part of the Jelenia Góra Basin. Here, a patch of gold-bearing sand and gravel covers an area of $c a .1 \mathrm{~km}^{2}$. It was mapped by Zimmermann (1937) and ascribed a Pliocene age. Later, Grodzicki (1967) demonstrated lithological similarities between these gravels and widespread gold-bearing deposits further north, near Lwówek Śląski and Złotoryja, considered as Pliocene and/or "pre-glacial". Gold-rich quartz veins in the Karkonosze granite were identified as the source of gravels north of Jelenia Góra.

\section{WEATHERING RESIDUALS}

Weathering residuals, even if not directly datable, have often proved to be useful tools to constrain long-term landform evolution (e.g., Simon-Coinçon et al., 1997; LidmarBergström et al., 1999).

In the granitic part of the Karkonosze Mts., thick mantles of disintegrated but minimally decomposed bedrock, classified as grus-type residuals, are widely present (Fig. 4; Migoń, 1997; Migoń and Thomas, 2002). Early observations were entirely qualitative and lacked mineralogical inquiry, but the renewal of interest in the 1990s (Migoń, 1997; Migoń and August, 2001)

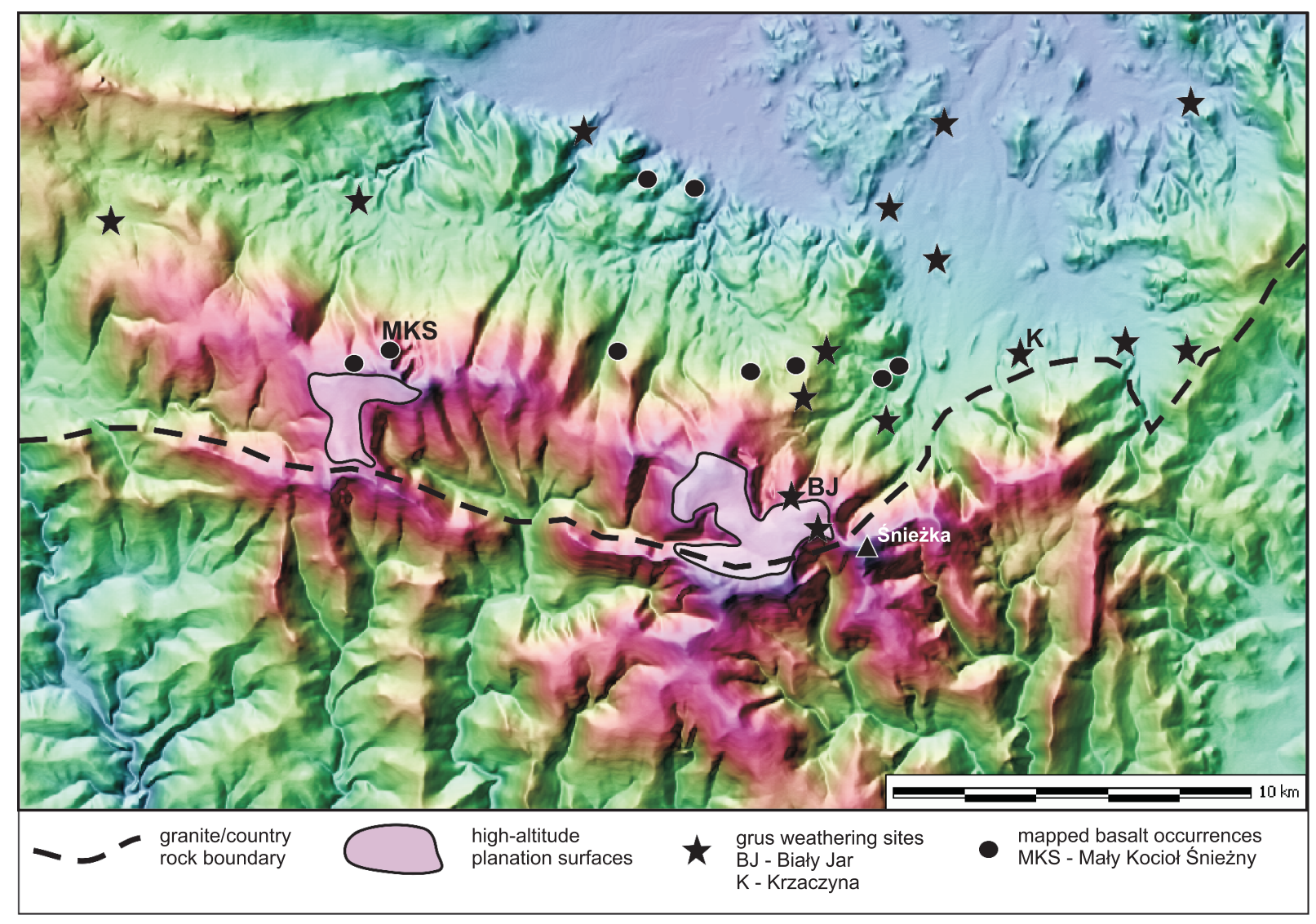

Fig. 4. Deep weathering of the Karkonosze granite 
has helped to establish the status of grus and its significance for long-term geological evolution.

The pattern of deep grus weathering is clearly controlled by local relief. Footslope settings host the thickest profiles (locally $>15 \mathrm{~m}$ ) and a few metres have been recorded in well-drained upper slope positions. The degree of mineralogical change in grus is generally minor: quartz, potassium feldspar and even biotite remain fresh. Plagioclase is usually affected first and the percentage of clay and silt fraction rarely exceeds $10 \%$. Smectite and illite are dominant secondary clays; kaolinite is either absent or occurs in trace quantities, although locally clayey infills with more kaolinite have been found along major joints. Considering all these characteristics, grus has been proposed to be a product of deep weathering which remains in long-term dynamic equilibrium with the landscape and environment, and in principle, should not be considered relict (Migoń, 2006b). Considerable local relief and the presence of numerous zones of structural weakness enhance deep groundwater circulation and allow for early disaggregation of rock, particularly in footslope settings.

The survival of older weathered mantles in the Karkonosze is problematic. August et al. (2007) described the presence of highly decomposed granite in Biały Jar, at $1300 \mathrm{~m}$ a.s.1., but suggested hydrothermal alteration to explain this unusual occurrence. More significantly, no clayey mantles have ever been reported from the Jelenia Góra Basin, despite an apparently good preservation potential in this enclosed intramontane depression. This stands in marked contrast with granite landscapes of the Sudetic Foreland, $\sim 50 \mathrm{~km}$ to the north-east, where thick sub-Miocene kaolinitic mantles are widely present. Hence, it seems unlikely that the current topography of the Karkonosze Granite Massif is older than Neogene.

\section{PLANATION SURFACES}

Planation surfaces used to be considered as the key markers of long-term erosion, and the situation in the Karkonosze Mts., where a prominent surface of low relief constitutes the backbone of the range (Fig. 4), was not different. A general agreement exists about pre-Quaternary inheritance of the flat watershed surfaces, but its age remains puzzling, largely due to the absence of any datable sediments or older weathering residuals associated with these surfaces.

Ouvrier (1933) mapped the extent of levelled surfaces and attempted their classification by altitude. Having found as many as 16 different levels, from 460 to $1440 \mathrm{~m}$ a.s.l., he inferred multi-phase, intermittent uplift of the Karkonosze area throughout the Tertiary. Landform evolution scenarios proposed in the 1950s and 1960s were more simple. Both Jahn (1954) and Sekyra (1964) criticized Ouvrier's views as too schematic, ignorant of sloping base level and geological control on surface evolution. Jahn (1954), working in the northern (Polish) part of the Karkonosze Mts., remarked that elements of flat relief at different altitudes do not need to be remnants of different cycles. Instead, they may have formed in one cycle which did not terminate with the origin of a "textbook" planation surface but presented a more varied relief. Sekyra
(1964), in turn, focused largely on the southern (Czech) part, underlain by metamorphic rocks. He identified two extensive tracts of planar relief at high elevation, the $P$ and $d P$ levels, and a series of mid-slope benches along major valleys. The former were considered as remnants of an Oligocene-Miocene surface, developed on granite and metamorphic rocks, respectively. Valley side benches would have recorded intermittent fluvial incision during the Late Neogene and Quaternary. The total magnitude of Quaternary incision was estimated at 55-70 m. However, it should be noted that no datable fluvial deposits have been found on benches elevated more than $20 \mathrm{~m}$ above the contemporary valley floor.

Very little conceptual advance in the interpretation of planation surfaces has occurred subsequently. The age of the summit surface, usually considered as Paleogene, has in reality remained unconstrained and speculative. Occasional suggestions that planation may have continued until the Late Miocene (Czerwiński, 1985) were based on the tentative interpretation of basalt bodies from the Mały Śnieżny Kocioł as truncated volcanic conduits of Miocene age. However, the recent re-examination of this basalt occurrence invalidated that hypothesis (Zagożdżon and Zagożdżon, 2006; see next section).

\section{CENOZOIC VOLCANISM}

Widespread volcanism affected the West Sudetes in the Cenozoic, leaving behind more than one hundred individual occurrences of volcanic rocks, from extensive lava plateaux to small dykes. Collectively, they are called the "Lower Silesia Basaltic Province" (Birkenmajer, 1967; Badura et al., 2005) and include basalts, basanites, tephrites, and phonolites. Radiometric ages obtained for a few tens of outcrops suggest a protracted period of volcanic activity, commencing in the Eocene and terminating in the Pliocene (Badura et al., 2005; Birkenmajer et al., 2007; Ulrych et al., 2011).

Despite the widespread distribution of basaltoids, there are only a few occurrences of Cenozoic volcanic rocks in the Karkonosze Mountains (Fig. 4). Berg (1940, 1941) reported only ten minor outcrops and admitted that some sites were mapped on the basis of loose clasts in slope deposits. Thus, it is likely that the actual number of basaltic dykes is higher, but their small size prevented identification (see Pilous, 1974).

Because of their small size, basaltic dykes in the Karkonosze were regarded as a local curiosity, not really worthy of further research. However, the first modern study on basaltoids in the Karkonosze was conducted by Zagożdżon and Zagożdżon (2006), who revisited the locality in the Mały Śnieżny Kocioł glacial cirque and identified one, relatively large (30-60 m wide and at least $120 \mathrm{~m}$ long) basanite body, not two small dykes as claimed earlier. They conclude that the western wall of the Mały Śnieżny Kocioł reveals the top part of a subvolcanic intrusion rather than a volcanic plug that once connected to the topographic surface. They also quote Pécskay et al. (2004) who dated the sample by K-Ar on a whole-rock sample and provided a late Oligocene age of $26 \pm 1.2 \mathrm{Ma}$.

The reinterpretation of the site in the Mały Śnieżny Kocioł has several implications for the long-term evolution of the 
Karkonosze. First, it casts a serious doubt on the view that a true volcano existed on the summit surface of the mountains. Second, the presence of basanite cannot be used to bracket the age of the summit plateau as the intrusion is not truncated by the topographic surface. Certainly, the site does not give any support to the assertion that the summit planation surface is post-Miocene. Third, it shows that magmatic activity in the Karkonosze may not have been associated with the main period of differential uplift and subsidence of the Sudetes, usually invoked for post-Mid-Miocene times (Dyjor, 1975; Zuchiewicz et al., 2007). However, the claim of Zagożdżon and Zagożdżon (2006) that basanite solidified at a depth of $c a .800 \mathrm{~m}$ is based on adoption of the mean denudation rate value of $0.031 \mathrm{~mm} \times$ $\mathrm{yr}^{-1}$ from Mierzejewski (1985), which is poorly constrained as indicated in Section 3. In reality, the depth of basanite emplacement is unknown.

\section{LOW-TEMPERATURE THERMOCHRONOLOGY}

Low-temperature thermochronology is used to measure the timing and rates at which rocks cool through crustal depths of few kilometres to the surface. Modern themochronological tools, such as fission track or (U-Th)/He systems, have sensitivity temperatures from $\sim 40$ to $\sim 300^{\circ} \mathrm{C}$, enabling a reconstruction of almost complete cooling trajectories within this temperature range. Depending on the geological setting, this cooling may be a result of exhumation (tectonic or erosional) and/or changes in thermal regime of the crust. In the first case, the cooling trajectories can be translated into an exhumation history by using the thermal structure of the crust to convert temperature information to depth. Thus, modern thermochronology can be a powerful tool to determine temporal changes in erosion rates or constrain the amount of missing volumes of rocks, and thus have unique potential for geomorphic studies.

Only a few thermochronological studies have been carried out on the Karkonosze granite and its surroundings (Jarmołowicz-Szulc, 1984; Martínek et al., 2005, 2006; Svojtka et al., 2005; Aramowicz et al., 2006; Danišík et al., 2010, 2012; Fig. 5). A pioneering thermochronological study was that of Jarmołowicz-Szulc (1984), when the fission track method was still being developed. Jarmołowicz-Szulc (1984) reported 25 apatite, 17 zircon and 4 sphene fission track ages (AFT, ZFT and SFT, respectively) from crystalline rocks collected from the northern Karkonosze granite and crystalline complexes further north, aimed at constraining the cooling history of the area. It should be emphasized that the data is now not to modern standards (e.g., numbers of counted grains are often too low, no elevation, no sample coordinates, no statistical test is presented, etc.). However, since the measured ages are remarkably consistent with the ages measured using modern instruments (Martínek et al., 2005, 2006; Svojtka et al., 2005; Danišík et al., 2010), they should not be disregarded.

SFT and ZFT ages from the Karkonosze granite (and within $5 \mathrm{~km}$ of its margin) range from $309 \pm 24 \mathrm{Ma}$ and $361 \pm$ $\pm 41 \mathrm{Ma}$ and are interpreted as cooling ages, recording cool- ing of the granite after its emplacement during Variscan orogeny. SFT and ZFT systems have similar closure temperatures most commonly referred to $275 \pm 25 \mathrm{Ma}$ and $240 \pm 50^{\circ} \mathrm{C}$, respectively (Hurford, 1986; Fitzgerald and Gleadow, 1988; Kohn et al., 1993). The data can be used to estimate maximum erosion when a reasonable value of palaeogeothermal gradient is assumed. The present-day geothermal gradient in the Karkonosze Mts. is $\sim 30^{\circ} \mathrm{C} / \mathrm{km}$, as estimated from surface heat flow ( $60 \mathrm{mWm}^{-2}$; Bruszewska, 2000) and thermal conductivity data $\left(2 \mathrm{Wm}^{-1} \mathrm{~K}^{-1}\right.$; Žák et al., 2006). Adopting this value as a long-term mean (although we admit it may have varied through time, yet to quantify this variability seems not possible at present), the closure temperatures noted and a surface temperature of $10^{\circ} \mathrm{C}$ gives a total erosion of $\sim 8 \mathrm{~km}$ since Carboniferous times.

AFT ages range from $63 \pm 8$ Ma to $121 \pm 10 \mathrm{Ma}$ and are interpreted as cooling ages, although this conclusion is not justified by track length data (Gleadow et al., 1986). Assuming a closure temperature of $\sim 100^{\circ} \mathrm{C}$ for the AFT system, Jarmołowicz-Szulc (1984) concluded the samples were at depth of $\sim 3 \mathrm{~km}$ in the Mid-Cretaceous, giving a reasonable value for the total erosion since that time. Taking all the data together, that author calculated average "uplift rates", that are in modern terminology understood as exhumation or erosion rates, to range from 30 to $50 \mathrm{~m} / \mathrm{Ma}$.

A group of Czech researchers applied AFT thermochronology to the upper Carboniferous to Lower Triassic ( $\sim 305-240 \mathrm{Ma})$ deposits of the Karkonosze Piedmont Basin located south of the Karkonosze crystalline basement. They presented four abstracts of largely identical content (Martínek et al., 2005, 2006; Svojtka et al., 2005) to report 14 AFT ages and thermal modelling based on track length data. All but one age are younger than the corresponding depositional age (AFT: 61-197 Ma), indicating an overall burial of $\geq 3 \mathrm{~km}$ during post-Early Triassic times (assuming a geothermal gradient of $30^{\circ} \mathrm{C} / \mathrm{km}$ ). These authors used inverse modelling to reconstruct cooling trajectories, which were then (incorrectly) interpreted in terms of uplift rates. The authors reconstructed the exhumation history of the samples and argued for an episodic style with four significant exhumation phases - i.e., in the Late Triassic-Mid-Jurassic (220-160 Ma), Cretaceous (130-90 Ma), Cretaceous-Paleocene (80-60 Ma) and Miocene-Pliocene (20-2 Ma), removing the pile of sediments accumulated prior to the Late Triassic. The modelling results and related interpretation are, however, difficult to assess because none of the critical information, such as raw data, counting statistics, details of modelling procedure, is reported. Therefore, the modelling results of the authors cannot be used as serious information and will be omitted from further interpretation

Danišík et al. (2010) used a combination of three different thermochronometers: zircon (U-Th)/He (ZHe), AFT and apatite (U-Th-[Sm])/He (AHe) systems applied to the same samples to constrain the long-term exhumation and erosion history of the basement and to constrain the age of the summit planation surface. The strategy of this study was based on the assumption that the summit planation surface formed during periods of tectonic quiescence by decay of previous topography into a low relief surface characterized by very low erosion rates. The combination of thermochronometers, which cover a 


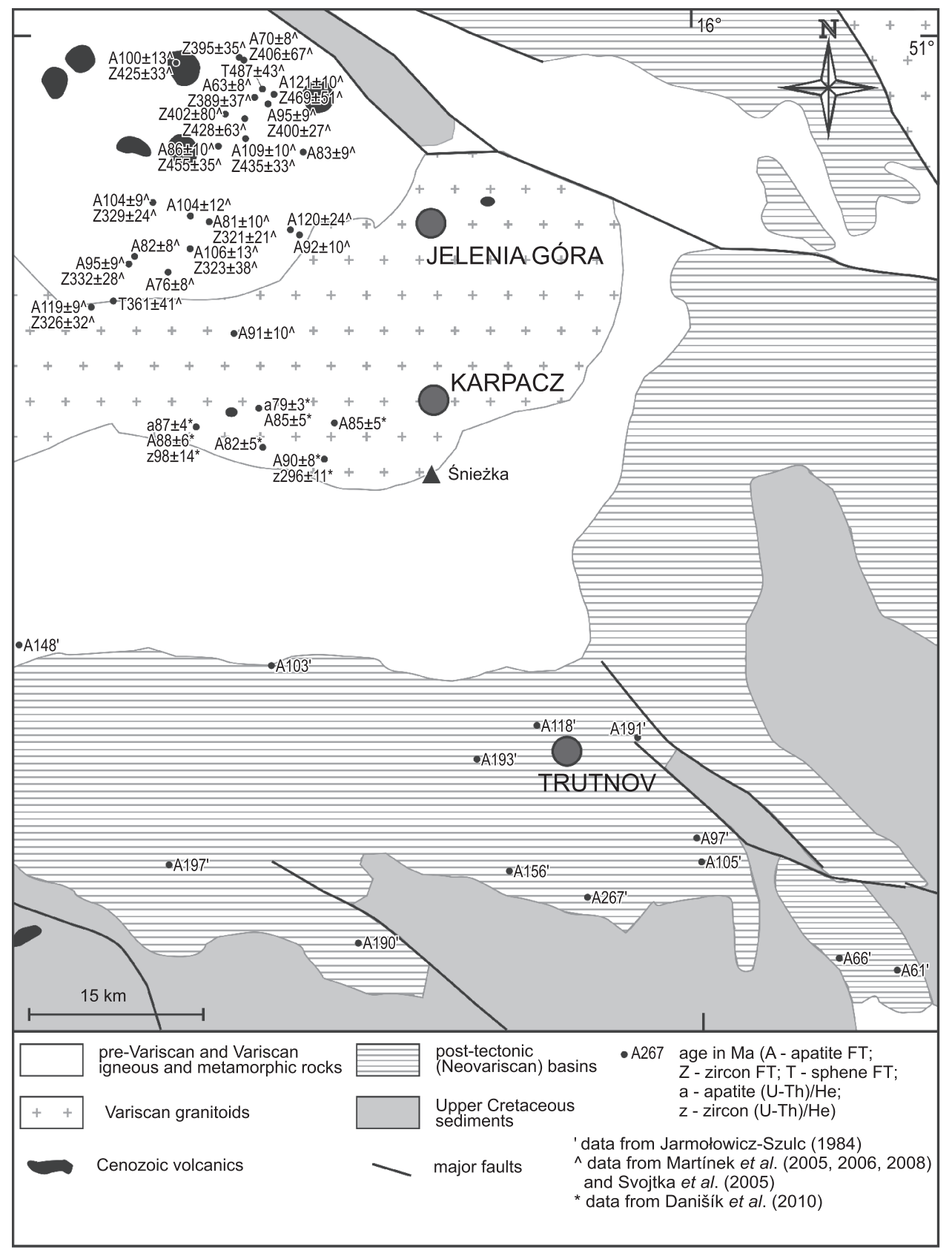

Fig. 5. Thermochronological data from the Karkonosze Massif and its immediate surroundings

temperature range of $\sim 190-40^{\circ} \mathrm{C}$, was applied to samples from the summit planation surface to reconstruct cooling trajectories, in an attempt to identify and bracket episodes of fast and slow cooling. These should correspond to the phases of exhumation and planation, respectively.

ZHe ages (closure temperature: $\sim 190^{\circ} \mathrm{C}$; ZHe Partial Retention Zone: $200-160^{\circ} \mathrm{C}$; Reiners et al., 2004) from two different localities form two distinct clusters. Samples from the western part of the planation surface are $285 \pm 19 \mathrm{Ma}, 295 \pm$ $\pm 20 \mathrm{Ma}$ and $308 \pm 21 \mathrm{Ma}$, implying that erosion during post-Permian times did not exceed $6 \mathrm{~km}$. In contrast, samples from the eastern part of the planation surface are Cretaceous $(86 \pm 6 \mathrm{Ma}, 91 \pm 6 \mathrm{Ma}$ and $97 \pm 7 \mathrm{Ma})$, implying that $>6 \mathrm{~km}$ of overburden must have been eroded since mid-Cretaceous times. AFT and AHe ages are almost identical, ranging from $82 \pm 5 \mathrm{Ma}$ to $90 \pm 8 \mathrm{Ma}$ and from $77 \pm 5 \mathrm{Ma}$ to $91 \pm 6 \mathrm{Ma}$, respectively, suggesting rapid cooling through the apatite fission track partial annealing and apatite helium partial retention zones $\sim 120-60^{\circ} \mathrm{C}$ (APAZ) and $\sim 85-40^{\circ} \mathrm{C}$ (HePRZ), respectively; Wagner and van den Haute (1992) and Wolf et al. (1998) during the Late Cretaceous. ZHe, AHe and AFT age and length data were used to model cooling trajectories, which are 
characterized by a two-stage cooling history: fast cooling through the APAZ and AHePRZ to surface conditions between $\sim 90$ and $\sim 75$ Ma was followed by slow cooling or thermal stagnation lasting from $\sim 75 \mathrm{Ma}$ until the present (Fig. 5). The variation point was placed into the time interval $\sim 85-75 \mathrm{Ma}$, as inferred from the youngest AHe ages measured. The cooling trajectories modelled were converted into exhumation rates, drawing the following major conclusions:

- average exhumation rates between 90-75 Ma and between $\sim 75 \mathrm{Ma}$ and the present were $\sim 300$ and $\sim 7 \mathrm{~m} / \mathrm{Ma}$, respectively. It was further emphasized that these values are associated with significant errors, but the two intervals identified differ by one to three orders of magnitude;

- since the mid-Cretaceous at least $3.6 \mathrm{~km}$ and, as shown by ZHe data, in some places $\sim 6 \mathrm{~km}$ of overburden has been removed, with the majority $(\geq 2.6-5 \mathrm{~km})$ being eroded between 100-75 Ma and less than $1.2 \mathrm{~km}$ afterwards, which is in agreement with the sedimentary record;

- widespread volcanism during Late Eocene to Early Miocene times did not affect the part of the basement studied as the data do not show any evidence of reheating during this interval.

Although a period of thermal stagnation was successfully identified, the age of the planation surface was not unequivocally resolved. The authors provide two alternative explanations: (i) the summit planation surface is a remnant of a peneplain that formed in the Permian, was buried by Mesozoic deposits and was exhumed and re-exposed in the Late Cretaceous. Alternatively (ii), the planation surface formed in the post-mid-Cretaceous as a result of the decay of substantial topographic relief, which existed in the Turonian and Coniacian and supplied detritus into the adjacent sedimentary basins. Since the thermochronological record of fast erosion ends at $\sim 75 \mathrm{Ma}$, it can be understood as the maximum age of the planation surface. The minimum age of the planation surface and the time of its uplift could not be resolved using the thermochronological data.

The data from the Karkonosze are consistent with those from the Lusatian Block to the west (Fig. 1A), reported by Ventura et al. (2009). AFT ages ranging between $\sim 95$ and $\sim 75 \mathrm{Ma}$ and slightly shorter mean (track lengths 13.6-14.1 $\mu \mathrm{m}$ ) imply a minimum denudation of $3 \mathrm{~km}$ of the Lusatian Block in the Late Cretaceous. These authors also proposed a later episode of denudation-related cooling of the order of $1 \mathrm{~km}$ by the end of the Paleogene, which is not identified in the Karkonosze. However, the two regions differ in their distance to the Eger Graben, the shoulders of which were subject to uplift in the mid-Cenozoic.

Aramowicz et al. (2006) reported AFT data (6 ages and 5 track length distributions) on the crystalline basement samples from the Góry Sowie Massif located $\sim 40 \mathrm{~km} \mathrm{E}$ of the Karkonosze. The ages $(57.5 \pm 3.5 \mathrm{Ma}$ to $43.0 \pm 2.5 \mathrm{Ma})$ and track length data (mean track lengths: 8.8-9.6 $\mu \mathrm{m}$ ) were used for inverse modelling of thermal trajectories. The modelling results suggest a cooling through the APAZ in the Late Cretaceous, re-heating to the APAZ in the mid-Cenozoic and a final cooling starting at 7-5 Ma, which is interpreted as being related to decrease of the geothermal gradient and/or increased tectonic activity in the Sudetes (Aramowicz et al., 2006). However, the validity of the authors' conclusions should be considered with great caution, because the quality of the dataset presented by Aramowicz et al. (2006) may be questioned: Firstly, the customary presentation of counting results on age standards expected from early career fission track analysts is missing. Secondly, the authors do not report the recommended chisquare statistics, so it is not possible to judge whether the grains belong to one age population and thus can be modelled (as they are) as one homogeneous population. In fact, high dispersion of single grain ages in radial plots (fig. 3 in Aramowicz et al., 2006) suggests the opposite for the majority of the samples, which might have introduced a flaw into the modelling results. Thirdly, the track length distributions, with a complete lack of $>13 \mu \mathrm{m}$ long tracks in all samples, is very atypical for apatite and to the best to our knowledge such track length data has not been reported previously. In our opinion, the track length distributions indicate a systematic error in the etching and/or track length measurement procedure. Incorrect track length information would introduce a serious flaw into the modelling and lead to erroneous results, which therefore cannot be considered correct. This in particular applies to the "recent" final cooling, which is clearly introduced by the lack of the long tracks. Fourthly, only one out of five samples is characterized by a sufficient number of track lengths, as required to provide a robust parameterization for the thermal modelling. Interestingly, only for this sample the modelling algorithm could not find good fit solutions, whereas for the rest of the samples characterized by too few track lengths and thus a higher degree of freedom, the model easily found enough good fits. This again argues against the reliability of the modelling results. Because of all these arguments, we disregard the modelling results and related conclusions of Aramowicz et al. (2006) for the interpretation of the Karkonosze area.

Much more relevant data for the Karkonosze area were recently reported by Danišík et al. (2012), although they come from an area located $\sim 90 \mathrm{~km}$ to the east. The authors investigated the Rychlebské hory Mts. in the Eastern Sudetes (Fig. 1A) by a combination of ZHe, AFT and AHe methods and found evidence for a regional burial of the Sudetes by the deposits of the BCB to $>6.5 \mathrm{~km}$ depth in the Late Cretaceous at 95-80 Ma. The most convincing arguments are reset $\mathrm{ZHe}$ ages on some basement blocks and, perhaps most importantly, the reset AFT system in a Turonian sandstone sample from the ISB. This implies burial depths of $>4 \mathrm{~km}$ during the Late Cretaceous and a much larger extent of the Cretaceous basin than suggested in the traditional "Sudetic Island" models (Scupin, 1913, 1936; Skoček and Valečka, 1983; Milewicz, 1997). Consequently, it can be speculated that even the Karkonosze area could have been buried in the Cretaceous. 


\section{LONG-TERM EVOLUTION OF THE KARKONOSZE - TOWARDS A SYNTHESIS}

Integration of the various sources of information reviewed in this paper, including new data published in the last decade, allows us to offer a new reconstruction of the long-term, post-exposure evolution of the Karkonosze granite area, different from the one presented by Mierzejewski (1985). There are still wide margins of uncertainty, associated particularly with those periods of geological time for which protracted gaps in sedimentary record around the Karkonosze Mts. exist. Nevertheless, the sequence of events is more comprehensive and up-to-date than any offered previously.

The history from the early Permian to the present is divided into 12 minor intervals of unequal duration (Table 1), characterized by denudation regimes different from the one present before and after the given interval. Therefore, some are geologically rather brief whereas others cover protracted time spans. A few have been distinguished on a different basis such as volcanism.
In a more generalized picture, during the long time span since the exposure of the Karkonosze granite we can distinguish three intervals of accelerated denudation and moderate to high relief in the granite terrain. These are the later part of the early Permian (early and mid-Saxonian), the Early Triassic, and particularly the Late Cretaceous. Erosion rates may have been as high as $300 \mathrm{~m} / \mathrm{Ma}$, as in the late Cretaceous. In addition, the later part of the Neogene (Pliocene?) and the Quaternary are typified by high relief, but lack the sedimentary evidence of corresponding accelerated erosion in the appropriate accommodation space of the Jelenia Góra Basin north of the Karkonosze Mts. Both the thermochronological and sedimentary records indicate a modest supply of sediment from the source area. Given the resolution of both records it is difficult to bracket the duration of these intervals with any greater precision, but timescales in the order of few million years are likely.

The intervals of significant geomorphic change were interspersed with much longer intervals (50-100 Ma), for which little evidence for rapid denudation exists and deposition may have temporarily occurred. These covered the time span from the Mid-Triassic to the Late Cretaceous and from the Paleogene

Long-term post-exposure history of the Karkonosze Granite Massif

\begin{tabular}{|c|c|c|c|}
\hline Phase & Period & $\begin{array}{l}\text { Denudation regime, processes and/or } \\
\text { other events in the Karkonosze }\end{array}$ & Evidence \\
\hline 1 & early Permian & $\begin{array}{l}\text { exposure of granite; coincident with regional } \\
\text { acceleration of denudation; high rates of erosion } \\
\text { in the contemporaneous Karkonosze Massif }\end{array}$ & $\begin{array}{l}\text { granite pebbles for the first time in sedimentary record; } \\
\text { predominance of coarse-grained clastics in the Saxonian } \\
\text { rock sequences; } \\
\text { braided river and alluvial fan environments, with occasional } \\
\text { debris flows }\end{array}$ \\
\hline 2 & late Permian & $\begin{array}{l}\text { diminished sediment supply and formation } \\
\text { of late Permian peneplain }\end{array}$ & $\begin{array}{l}\text { fining of deposition, lacustrine and aeolian environments, } \\
\text { evidence of advanced pedogenesis (calcretes) }\end{array}$ \\
\hline 3 & Early Triassic & acceleration of denudation & sandy deposition in the North Sudetic Trough \\
\hline 4 & Middle Triassic & denudation ceases; possible deposition & $\begin{array}{l}\text { termination of sandy deposition, replacement by carbonate } \\
\text { sediments with little terrigenous input }\end{array}$ \\
\hline 5 & $\begin{array}{l}\text { Late Triassic-Early/Late } \\
\text { Cretaceous }\end{array}$ & $\begin{array}{l}\text { low rates of denudation (possibly intermittent } \\
\text { deposition); deep weathering } \\
\text { note that this period is a major "unknown" }\end{array}$ & $\begin{array}{l}\text { Late Triassic deposits finer than their older deposits; } \\
\text { deeply weathered basement surfaces elsewhere } \\
\text { in the Bohemian Massif, including Lusatia }\end{array}$ \\
\hline 6 & $\begin{array}{c}\text { Late Cretaceous } \\
\text { (Cenomanian-Coniacian) }\end{array}$ & $\begin{array}{c}\text { differential uplift/subsidence } \\
\text { of fault-bounded blocks; } \\
\text { major denudation, with the peak in the Turonian }\end{array}$ & $\begin{array}{l}\text { thick sandstone sequences, mainly from the Turonian; } \\
\text { rapid cooling in thermochronological record }\end{array}$ \\
\hline 7 & $\begin{array}{l}\text { latest Cretaceous/earliest } \\
\text { Paleogene }\end{array}$ & $\begin{array}{l}\text { activity of fault network, exemplified by the } \\
\text { Lusatian Fault; } \\
\text { possibly tectonic component in denudation }\end{array}$ & $\begin{array}{l}\text { deformation of Cretaceous sediments along } \\
\text { the Lusatian Fault }\end{array}$ \\
\hline 8 & Paleogene & $\begin{array}{l}\text { very low rates of denudation and limited coarse } \\
\text { sediment supply }\end{array}$ & $\begin{array}{c}\text { thermal stagnation in thermochronological record from the } \\
\text { planation surfaces; } \\
\text { gap in sedimentary record around the Sudetes } \\
\text { until the Late Eocene; } \\
\text { deeply weathered basement surfaces elsewhere } \\
\text { in the Bohemian Massif }\end{array}$ \\
\hline 9 & $\begin{array}{l}\text { late Paleogene } \\
\text { (Oligocene) }\end{array}$ & volcanism & $\begin{array}{c}\text { subvolcanic bodies and basalt dykes in the Karkonosze } \\
\text { and Jizerske hory }\end{array}$ \\
\hline 10 & Early to Middle Miocene & low rates of denudation & thermal stagnation in thermochronological record \\
\hline 11 & $\begin{array}{l}\text { late Neogene } \\
\text { (Late Miocene-Pliocene) }\end{array}$ & $\begin{array}{l}\text { differential surface uplift but apparently little } \\
\text { corresponding denudation }\end{array}$ & $\begin{array}{l}\text { tectonic landforms and morphometric indices typical } \\
\text { for young mountain fronts; } \\
\text { sand and gravel deposition in the Jelenia Góra Basin; } \\
\text { no evidence of accelerated cooling of rocks }\end{array}$ \\
\hline 12 & early Pleistocene & $\begin{array}{l}\text { topography similar to the current one dictates } \\
\text { the pattern of mountain glaciation } \\
\text { in the Pleistocene }\end{array}$ & glacial cirques incised into the current summit plateau \\
\hline
\end{tabular}


to the Late Miocene. The examination of a wider Central European context (see Migoń and Lidmar-Bergström, 2001) suggests that deep weathering of granite typified these long intervals and thick weathering mantles were formed. Stripping was largely confined to weathering products, whereas a significant degree of denudation may have resulted from solute export. However, it is also possible that minor "cycles" of relief formation and decay occurred within these two broadly defined intervals, particularly the former one, but none has left a record which can be interpreted with confidence, either from sedimentary history or thermochronology. Mid-Cretaceous ZHe ages referred to in the previous section, implying the the basement samples were at depth of $>6 \mathrm{~km}$ at that time, offer two alternative interpretations. They may have been close to the surface as a part of the Permian "peneplain" and buried later by a few kilometres-thick pile of long gone Cretaceous strata as inferred from the East Sudetes (Danišík et al., 2012). Alternatively, but less likely, they resided above the zircon helium partial retention zone throughout the Permian and most of the Mesozoic.

How thick, then, is the missing column of granite rock? Cloos (1925) envisaged that 2-2.5 km was eroded from the axial part of the Karkonosze dome, a figure accepted by Mierzejewski (1985) in his reconstruction. However, this is inconsistent with thermochronological data (Jarmołowicz-Szulc, 1984; Danišík et al., 2010) suggesting that $3.6 \mathrm{~km}$ of overburden must have been eroded since the Turonian alone. Results of $\mathrm{ZHe}$ analysis show that in places erosion of $\sim 6 \mathrm{~km}$ of rock must have taken place. Even if we assume that a part of the eroded rock column consisted largely of Cretaceous deposits, a picture involving much deeper unroofing of the granite body than suggested by Cloos (1925) emerges.

Despite the advances in our understanding of the long-term history of the Karkonosze granite terrain, important challenges for the future remain. First, the reasons for accelerated denuda- tion in discrete intervals of geological time must be better explained. Stresses transmitted from the Alpine (Ziegler and Dèzes, 2007) or Pyrenean collisions (Kley and Voigt, 2008) are usually invoked but the exact mechanisms, causes and effects are poorly specified. Second, little is known about the surface processes operating during the various phases of evolution distinguished in this paper. For instance, the extent to which the contemporary geomorphic system (with its process-form relationships) is representative of the past, remains unaddressed. For example, deep-seated landslides currently do not occur in the Karkonosze Mts., but they are the norm in deeply weathered granite terrains in the inter-tropical zone and account for fast sediment transfer from hillslopes through the fluvial systems beyond the mountains (Migoń, 2010). Third, some uncertainty remains regarding the tectonic history of the fault system(s) in the Sudetes during the period of widespread basin inversion in Central and Western Europe (Adamovič and Coubal, 1999) and particularly, the magnitude of uplift along the faults and their impact on the geological evolution of the Karkonosze area. Finally, an extension of the thermochronological dataset focused on sampling individual basement blocks as well as syn- and post-tectonic strata should help to further constrain the timing of erosion of the Karkonosze Granite Massif.

Acknowledgements. Financial support for research to PM was provided by the University of Wrocław (internal grant 2024/W). We thank J. Wojewoda for comments on the sedimentary history section of the paper. The English language was improved by N. Evans (CSIRO, Earth Science and Resource Engineering/John de Laeter Centre of Isotope Research, Perth). T. Voigt (Jena) and two anonymous reviewers are thanked for their constructive remarks on the first version of the paper.

\section{REFERENCES}

ADAMOVIČ J. and COUBAL M. (1999) - Intrusive geometries and Cenozoic stress history of the northern part of the Bohemian Massif. GeoLines, 9: 5-14.

ALEKSANDROWSKI P. and MAZUR S. (2002) - Collage tectonics in the northeasternmost part of the Variscan belt: the Sudetes, Bohemian Massif. Geol. Soc. Spec. Publ., 201: 237-277.

ARAMOWICZ A., ANCZKIEWICZ A.A. and MAZUR S. (2006) - Fission-track dating of apatite from the Góry Sowie Massif, Polish Sudetes, NE Bohemian Massif: implications for post-Variscan denudation and uplift. N. Jb. Miner. Abh., 182 (3): 221-229.

AUGUST C., MIERZEJEWSKI M.P. and ĆWIĄKALSKI J. (2007) - Unusual occurrence of smectite within the Karkonosze granite in Biały Jar near Mt. Śnieżka. Opera Corcont., 44 (1): 61-66.

BADURA J. and PRZYBYLSKI B. (2004) - Evolution of the Late Neogene and Eopleistocene fluvial system in the foreland of the Sudetes Mountains, SW Poland. Ann. Soc. Geol. Pol., 74: 43-61.

BADURA J., PÉCSKAY Z., KOSZOWSKA E., WOLSKA A., ZUCHIEWICZ W. and PRZYBYLSKI B. (2005) - New age and petrological constraints on Lower Silesian basaltoids, SW Poland. Acta Geodyn. Geomater., 2 (3/139): 7-15.
BADURA J., ZUCHIEWICZ W., ŠTĚPANČIKOVÁ P., PRZYBYLSKI B., KONTNY B. and CACOŃ S. (2007) - The Sudetic Marginal Fault: a young morphotectonic feature at the NE margin of the Bohemian Massif, Central Europe. Acta Geodyn. Geomater., 4 (4): 7-29.

BERG G. (1927) - Zur Morphologie des Riesengebirges. Z. Geomorph., 2: $1-20$.

BERG G. (1938) - Erläuterungen zu Blatt Landeshut, Lieferung 193. Preuss. Geol. Landesanst, Berlin.

BERG G. (1940) - Geologische Karte des Deutschen Reiches 1:25 000. Lieferung 241. Erläuterungen zu Blatt Krummhübel.

BERG G. (1941) - Geologische Karte des Deutschen Reiches 1:25 000. Lieferung 241. Erläuterungen zu Blatt Schreiberhau Schneegrubenbaude.

BIRKENMAJER K. (1967) - Lower Silesian basalts as monuments of inanimate nature (in Polish with English summary). Ochr. Przyr., 32: 225-276.

BIRKENMAJER K., PÉCSKAY Z., GRABOWSKI J., LORENC M.W. and ZAGOŻDŻON P.P. (2007) - Radiometric dating of the Tertiary volcanics in Lower Silesia, Poland. IV. Further K-Ar and palaeomagnetic data from Late Oligocene to Early Miocene basaltic 
rocksof the Fore-Sudetic Block - 1-19. Ann. Soc. Geol. Pol., 77 (1): $1-16$.

BLECHA M., BURLIGA S., LOJKA R., MARTÍNEK K. and WOJEWODA J. (2008) - Osady permskie basenu śródsudeckiego. In: Polska Konferencja Sedymentologiczna POKOS'3, Kudowa Zdrój, 15-21.09.2008: 61-83.

BRUSZEWSKA B. (2000) - The geothermal conditions in the Lower Silesia (SW Poland) (in Polish with English summary). Prz. Geol., 48 (7): 639-643.

BURLIGA S., MARTÍNEK K. and WOJEWODA J. (2008) - Perm podkarkonoskiego basenu piedmontowego i basenu Nachodu. In: Polska Konferencja Sedymentologiczna POKOS'3, Kudowa Zdrój, 15-21.09.2008: 84-110.

CLOOS H. (1925) - Einführung in die tektonische Behandlung magmatischer Erscheinungen (Granittektonik). Gebrüder Borntraeger, Berlin.

COUBAL M. (1990) - Compression along faults: example from the Bohemian Cretaceous Basin. Miner. Slovaca, 22: 139-144.

CZERWIŃSKI J. (1985) - Główne cechy rzeźby i rozwój geomorfologiczny. In: Karkonosze polskie (ed. A. Jahn): 53-76. Ossolineum, Wrocław

DANIŠÍK M., MIGOŃ P., KUHLEMANN J., EVANS N.J., DUNK1 I. and FRISCH W. (2010) - Thermochronological constraints on the long-term erosional history of the Karkonosze Mts., Central Europe. Geomorphology, 117: 78-89.

DANIŠÍK M., ŠTĚPANČÍKOVÁ P. and EVANS N.J. (2012) - Constraining long-term denudation and faulting history in intraplate regions by multi-system thermochronology - an example of the Sudetic Marginal Fault (Bohemian Massif, Central Europe). Tectonics, doi:10.1029/2011TC003012.

DON J., JERZYKIEWICZ T., TEISSEYRE A.K. and WOJCIECHOWSKA I. (1981) - Objaśnienia do szczegółowej mapy geologicznej Sudetów 1:25 000, ark. Lubawka. Wyd. Geol., Warszawa.

DUTHOU J.-L., COUTURIE J.P., MIERZEJEWSKI M.P. and PIN C. (1991) - Next dating of granite samples from the Karkonosze Mountains using $\mathrm{Rb}-\mathrm{Sr}$ total rock's isochrones method (in Polish with English summary). Prz. Geol., 39 (2): 75-78.

DYJOR S. (1970) - The Poznań Series in west Poland (in Polish with English summary). Kwart. Geol., 14 (4): 819-835.

DYJOR S. (1974) - The Oligocene of the Lowland section of Lower Silesia (in Polish with English summary). Biul. Inst. Geol., 281: 119-138.

DYJOR S. (1975) - Late Tertiary tectonic movements in the Sudety Mts. and Fore-Sudetic Block. In: Recent and Neotectonic Crustal Movements in Poland (in Polish with English summary) (ed. W.C. Kowalski): 121-132. Wyd. Geol., Warszawa.

DYJOR S. (1986) - Evolution of sedimentation and palaeogeography of near-frontier areas of the Silesian part of the Paratethys and the Tertiary Polish-German Basin. Geologia, Kwart. AGH, 12 (3): 7-23.

DYJOR S. (1992) - Evolution of sedimentation and process of alterations of sediments in the Poznan suite in Poland (in Polish with English summary). Acta Univ. Wratisl., 1354, Pr. Geol.-Miner., 26 (2): 3-18.

FITZGERALD P.G. and GLEADOW A.J.W. (1988) - Fission-track geochronology, tectonics and structure of the Transantarctic Mountains in northern Victoria Land, Antarctica. Chem. Geol., 73: 1497-1502.

GLEADOW A.J.W., DUDDY I.R. and GREEN P.F. (1986) - Confined fission track lengths in apatite: a diagnostic tool for thermal history analysis. Contrib. Miner. Petrol., 94: 405-415.

GRODZICKI A. (1967) - On the occurrence of gold-bearing sands in the vicinities of Jelenia Góra (in Polish with English summary). Prz. Geol., 15 (6): 285-289.

HURFORD A.J. (1986) - Cooling and uplift patterns in the Lepontine Alps, South Central Switzerland and an age of vertical movement on the Insubric fault line. Contrib. Miner. Petrol., 92: 413-427.

JAHN A. (1954) - Karkonosze - rys morfologiczny. Czas. Geogr., 23/24: $107-121$.
JARMOŁOWICZ-SZULC K. (1984) - Geochronological study of a part of the northern cover of the Karkonosze granite by fission track method (in Polish with English summary). Arch. Miner., 39: 139-183.

JAROSIŃSKI M., POPRAWA P. and ZIEGLER P.A. (2009) - Cenozoic dynamic evolution of the Polish Platform. Geol. Quart., 53 (1): 3-26.

KASIŃSKI J.R. and PANASIUK M. (1987) - The origin and evolution of the Zittau Depression (in Polish with English summary). Biul. Inst. Geol., 357: 5-35.

KLEY J. and VOIGT T. (2008) - Late Cretaceous intraplate thrusting in central Europe: effect of Africa-Iberia-Europe convergence, not Alpine collision. Geology, 36: 839-842.

KOHN B.P., WAGNER M.E., LUTZ T.M. and ORGANIST G. (1993) Anomalous Mesozoic thermal regime, central Appalachian Piedmont: evidence from sphene and zircon fission-track dating. J. Geol., 101: 779-794.

KOZDRÓJ W., KRENTZ O. and OPLETAL M. (2001) - Geological map and comments on the Geological Map Lausitz, Jizera, Karkonosze (without Cenozoic sediments) 1:100 000. Państw. Inst. Geol., Warsaw.

KRZYSZKOWSKI D., MIGOŃ P. and SROKA W. (1995) - Neotectonic Quaternary history of the Sudetic Marginal Fault, SW Poland. Fol. Quartern., 66: 73-98.

KRZYWIEC P. (2006) - Structural inversion of the Pomeranian and Kuiavian segments of the Mid-Polish Trough - lateral variations in timing and structural style. Geol. Quart., 50 (1): 151-167.

KUHLEMANN J. (2000) - Post-collisional sediment budget of circum-Alpine basins (Central Europe). Mem. Sc. Geol. (Padova), 52: 1-91.

LIDMAR-BERGSTRÖM K., OLSSON S. and ROALDSET E. (1999) Relief features and palaeoweathering remnants in formerly glaciated Scandinavian basement areas. IAS Spec. Publ., 27: 275-301.

LORENC S. and MROCZKOWSKI J. (1978) - The sedimentation and petrography of Zechstein and lowermost Triassic deposits in the vicinity of Kochanów (Intra-Sudetic Trough). Geol. Sudet., 13 (2): 23-39.

MACHOWIAK K. and ARMSTRONG R. (2007) - SHRIMP U-Pb zircon age from the Karkonosze granite. Miner. Pol.-Spec. Pap., 31: 193-196.

MALKOVSKÝ M. (1979) - Tektogeneze platformního pokryvu Ceského Masívu. Czech. Ustřed. Ustav Geol., Praha.

MALKOVSKÝ M. (1987) - The Mesozoic and Tertiary basins of the Bohemian Massif and their evolution. Tectonophysics, 137: 31-42.

MARHEINE D., KACHLIK V., MALUSKI H., PATOČKA F. and ŻELAŹNIEWICZ A. (2002) - The ${ }^{40} \mathrm{Ar}-{ }^{39} \mathrm{Ar}$ ages from the West Sudetes (NE Bohemian Massif): constraints on the Variscan polyphase tectonothermal development. Geol. Soc. Spec. Publ., 201: 133-155.

MARTÍNEK K., SVOJTKA M. and FILIP J. (2006) - Reconstructing post-Carboniferous history of the Krkonoše Piedmont Basin using detrital apatite fission-track data. Geolines, 20: 91-92.

MARTÍNEK K., SVOJTKA M. and FILIP J. (2008) - Multiphase cooling and exhumation of the Krkonoše Piedmont Basin during Mesozoic Cenozoic basin inversion based on apatite fission track analysis. In: The 33rd International Geological Congress, Oslo, August 6-14th, abstract, 1 page.

MASTALERZ K. (1990) - Lacustrine successions in fault bounded basins: Upper Anthracosia Shale (Lower Permian) of the North Sudetic Basin, SW Poland. Ann. Soc. Geol. Pol., 60 (1-4): 75-103.

MAZUR S., ALEKSANDROWSKI P., KRYZA R. and OBERC-DZIEDZIC T. (2006) - The Variscan Orogen in Poland. Geol. Quart., 50 (1): 89-118.

MIERZEJEWSKI M.P. (1985) - Denudation of the ancient Karkonosze Mts during Permo-Carboniferous and Mesozoic era (in Polish with English summary). Geol. Sudet., 20 (1): 197-225.

MIGOŃ P. (1991) - The origin of stepped topography in the northern part of the Karkonosze granite massif. Bull. Pol. Acad. Sc., Earth Sc., 39: 267-276.

MIGOŃ P. (1997) - Palaeoenvironmental significance of grus weathering profiles: a review with special reference to northern and central Europe. Proc. Geol. Ass., 108: 57-70.

MIGOŃ P. (2006a) - Granite Landscapes of the World. Oxford University Press, Oxford. 
MIGOŃ P. (2006b) - Grus weathering mantles as indicators of long-term geomorphic instability. Quaest. Geogr., 25A: 49-55.

MIGOŃ P. (2010) - Mass movement and landscape evolution in weathered granite and gneiss terrains. Geol. Soc., Eng. Geol. Spec. Publ., 23: $33-45$.

MIGOŃ P. and AUGUST C. (2001) - Cechy litologiczne zwietrzelin ziarnistych masywu karkonosko-izerskiego. In: Geneza, litologia i stratygrafia utworów czwartorzędowych, vol. III (ed. A. Kostrzewski): 283-305. Wyd. Nauk. UAM, Poznań.

MIGOŃ P. and LIDMAR-BERGSTRÖM K. (2001) - Weathering mantles and their significance for geomorphological evolution of central and northern Europe since the Mesozoic. Earth Sc. Rev., 56: 285-324.

MIGOŃ P. and THOMAS M.F. (2002) - Grus weathering mantles - problems of interpretation. Catena, 49: 5-24.

MILEWICZ J. (1965) - Rotliegende deposits in the vicinity of Lwówek Śląski (in Polish with English summary). Biul. Inst. Geol., 185: 195-228.

MILEWICZ J. (1997) - Upper Cretaceous of the North-Sudetic depression (litho- and biostratigraphy, paleogeography, tectonics and remarks on Raw materials (in Polish with English summary). Acta Univ. Wratisl., 1971, Pr. Geol.-Miner., 61: 1-58.

MROCZKOWSKI J. (1972) - Sedimentation of the Bunter in the North-Sudetic Basin (in Polish with English summary). Acta Geol. Pol., 22 (2): 351-377.

MROCZKOWSKI J. (1977) - Lower Triassic sandstones in the northern part of the Intra-Sudetic Trough (in Polish with English summary). Rocz. Pol. Tow. Geol., 47 (1): 49-72.

MROCZKOWSKI J. and SKOWRONEK C. (1980) - Rotliegendes deposits in the North-eastern North-Sudetic Trough (Sudetes Mts): their depositional environment and possibile stratigraphic implications (in Polish with English summary). Geol. Sudet., 15 (1): 125-142.

OBERC J. and DYJOR S. (1973) - Progress of Late Tertiary erosion in the Leśna area, the Sudety (in Polish with English summary). Prz. Geol., 21 (4): 177-182.

OUVRIER H. (1933) - Beiträge zur Morphologie des Hohen Riesengebirges. Veröffentl. Schles. Ges. Erdk., 17: 1-88.

PÉCSKAY Z., LORENC M.W., BIRKENMAJER K. and ZAGOŻDŻON P.P. (2004) - Recent geochronological studies of Tertiary volcanics in Lower Silesia, Poland. In: International Workshop "Basalts 2004": 24-25.

PILOUS V. (1974) - Nové naleziště čediče v západních Krkonoších. Opera Corcontica, 11: 203-205.

PIN C., MIERZEJEWSKI M.P. and DUTHOU J.-L. (1987) - Isochronous age $\mathrm{Rb} / \mathrm{Sr}$ of Karkonosze granite from the quarry Szklarska Poręba Huta and significance of initial ratio ${ }^{87} \mathrm{Sr} /{ }^{86} \mathrm{Sr}$ in this granite (in Polish with English summary). Prz. Geol., 35 (10): 512-517.

PIWOCKI M. (2004) - Niż Polski i jego południowe obrzeżenie Paleogen. In: Budowa Geologiczna Polski (eds. T. Peryt and M. Piwocki). Kenozoik, Paleogen, Neogen, 3a: 22-70. Państw. Inst. Geol., Warszawa.

PIWOCKI M., BADURA J. and PRZYBYLSKI B. (2004) - Niż Polski i jego południowe obrzeżenie - Neogen. In: Budowa Geologiczna Polski (eds. T. Peryt and M. Piwocki). Kenozoik, Paleogen, Neogen, 3a: 71-118. Państw. Inst. Geol., Warszawa.

PROSOVÁ M. (1974) - Geneze reliktního terciéru. Univerzita Karlova, Praha.

RACZYŃSKI P. (1997) - Depositional conditions and paleoenvironments of the Zechstein deposits in the North-Sudetic Basin (SW Poland) (in Polish with English summary). Prz. Geol., 45 (7): 693-699.

REICHERTER K., FROITZHEIM N., JAROSIŃSKI M., BADURA J., FRANZKE H.-J., HANSEN M., HÜBSCHER C., MÜLLER R., POPRAWA P., REINECKER J., STACKENBRANDT W., VOIGT T., von EYNATTEN H. and ZUCHIEWICZ W. (2008) - Alpine tectonics north of the Alps. In: The Geology of Central Europe. Volume 2: Mesozoic and Cenozoic (ed. T. McCann): 1233-1285. Geol. Soc., London.

REINERS P.W., SPELL T.L., NICOLESCU S. and ZANETTI K.A. (2004) - Zircon (U-Th)/He thermochronometry: He diffusion and comparisons with ${ }^{40} \mathrm{Ar} /{ }^{39} \mathrm{Ar}$ dating. Geochim. Cosmochim. Acta, 68: 1857-1887.
SCHECK M., BAYER U., OTTO V., LAMARCHE J., BANKA D. and PHARAOH T. (2002) - The Elbe Fault System in North Central Europe - a basement controlled zone of crustal weakness. Tectonophysics, 360: 281-299.

SCHECK-WENDEROTH M., KRZYWIEC P., ZÜHLKE R., MAYSTRENKO Y. and FROITZHEIM N. (2008) - Permian to Cretaceous tectonics. In: The Geology of Central Europe. Volume 2: Mesozoic and Cenozoic (ed. T. McCann): 999-1030. Geol. Soc., London.

SCUPIN H. (1913) - Die löwenberger Kreide und ihre Fauna. Palaeontographica, 6.

SCUPIN H. (1936) - Zur Palaeographie des sudetischen Kreidemeeres. Z. dt. geol. Ges., 88: 309-325.

SEKYRA J. (1964) - Kvarterní geologické a geomorfologické problemy krkonošského krystalinika. Opera Corcont., 1: 7-24.

SIMON-COINÇON R., THIRY M. and SCHMITT J.-M. (1997) - Variety and relationships of weathering features along the early Tertiary palaeosurface in the southwestern French Massif Central and nearby Aquitaine Basin. Palaeogeogr. Palaeoclimatol. Palaeoecol., 129: 51-79.

SKOČEK V. and VALEČKA J. (1983) - Palaeogeography of the Late Cretaceous Quadersandstein of Central Europe. Palaeogeogr. Palaeoclimatol. Palaeoecol., 44: 71-92.

ŚLIWIŃSKI W. (1980) - A model for caliche formation in the continental Permian deposits of southeastern Intra-Sudetic Basin, southwestern Poland (in Polish with English summary). Geol. Sudet., 15 (2): 83-104.

ŠTĚPANČÍKOVÁ P., HÓK J., NÝVLT D., DOHNAL J., SÝKOROVÁ I. and STEMBERK J. (2010) - Active tectonics research using trenching technique on the south-eastern section of the Sudetic Marginal Fault (NE Bohemian Massif, central Europe). Tectonophysics, 485: 269-282.

SVOJTKA M., FILIP J. and MARTÍNEK K. (2005) - Cooling and erosion history of the Krkonoše Piedmont Basin (Bohemian Massif, Czech Republic) interpreted from apatite fission-track analysis. Geophys. Res. Abstracts, 7: 04925.

TURNAU E., ŻELAŹNIEWICZ A. and FRANKE W. (2002) - Middle to Early late Visean onset of late orogenic sedimentation in the Intra-Sudetic Basin, West Sudetes: miospore evidence and tectonic implication. Geol. Sudet., 34: 9-16.

ULIČNÝ D. (2001) - Depositional systems and sequence stratigraphy of coarse-grained deltas in a shallow-marine, strike-slip setting: the Bohemian Cretaceous Basin, Czech Republic. Sedimentology, 48: 599-628.

ULIČNÝ D., ČECH S. and GRYGAR R. (2003) - Tectonics and depositional systems of a shallow-marine, intra-continental strike-slip basin: Exposures of the Český Ráj region, Bohemian Cretaceous Basin. Geolines, 6: 133-148.

ULRYCH J., DOSTÁL J., ADAMOVIČ J., JELÍNEK E., ŠPAČEK P., HEGNER E. and BALOGH K. (2011) - Recurrent Cenozoic volcanic activity in the Bohemian Massif (Czech Republic). Lithos, doi: 10.1016/j.lithos.2010.12.008

VENTURA B., LISKER F. and KOPP J. (2009) - Thermal and denudation history of the Lusatian Block (NE Bohemian Massif, Germany) as indicated by apatite fission-track data. Geol. Soc. Spec. Publ., 324: 181-192.

VOIGT T. (2009) - Die Lausitz-Riesengebirgs-Antiklinalzone als kreidezeitliche Inversionsstruktur: Geologische Hinweise aus den umgebenden Kreidebecken. Z. geol. Wiss., 37: 15-39.

WAGNER G.A. and van den HAUTE P. (1992) - Fission-Track Dating. Enke Verlag, Stuttgart.

WOJEWODA J. (1997) - Upper Cretaceous littoral-to-shelf succession in the Intrasudetic Basin and Nysa Trough, Sudety Mts. In: Obszary źródłowe: zapis w osadach (ed. J. Wojewoda): 81-96. Wind, Wrocław.

WOJEWODA J. and MASTALERZ K. (1989) - Climate evolution, alloand autocyclicity of sedimentation: an example from the Permo-Carboniferous continental deposits of the Sudetes, SW Poland (in Polish with English summary). Prz. Geol., 43 (4): 173-180.

WOLF R.A., FARLEY K.A. and KASS D.M. (1998) - Modeling of the temperature sensitivity of the apatite $(\mathrm{U}-\mathrm{Th}) / \mathrm{He}$ thermochronometer. Chem. Geol., 148: 105-114. 
ZAGOŻDŻON P.P. and ZAGOŻDŻON K. (2006) - Characteristics of the Oligocene basaltoid in the Mały Kocioł Śnieżny (Karkonosze Mountains) (in Polish with English summary). Prz. Geol., 54 (6): 496-500.

ZIEGLER P.A. and DÈZES P. (2007) - Cenozoic uplift of Variscan Massifs in the Alpine foreland: timing and controlling mechanisms. Global Planet. Change, 58: 237-269.

ZIMMERMANN E. (1937) - Erläuterungen zu Blatt Hirschberg, Lieferung 276. Preuss. Geol. L.-A., Berlin.
ZUCHIEWICZ W., BADURA J. and JAROSINSKI M. (2007) Neotectonics of Poland: an overview of active faulting. Stud. Quatern., 24: 5-20.

ŽÁK J., VYHNÁLEK B. and KABELE P. (2006) - Is there a relationship between magmatic fabrics and brittle fractures in plutons? A view based on structural analysis, anisotropy of magnetic susceptibility and thermo-mechanical modelling of the Tanvald pluton (Bohemian Massif). Phys. Earth Planet. Inter., 157: 286-310. 